\title{
Dressing a Wolf in Sheep's Clothing: Toward Understanding the Composition of the Life of Alexander Nevskii
}

\section{Citation}

Ostrowski, Donald. 2013. Dressing a wolf in sheep's clothing: Toward understanding the composition of the Life of Alexander Nevskii. Russian History 40(1): 41-67.

\section{Published Version}

doi:10.1163/18763316-04001004

\section{Permanent link}

http://nrs.harvard.edu/urn-3:HUL.InstRepos:10502406

\section{Terms of Use}

This article was downloaded from Harvard University's DASH repository, and is made available under the terms and conditions applicable to Other Posted Material, as set forth at http:// nrs.harvard.edu/urn-3:HUL.InstRepos:dash.current.terms-of-use\#LAA

\section{Share Your Story}

The Harvard community has made this article openly available. Please share how this access benefits you. Submit a story.

Accessibility 


\title{
Dressing a Wolf in Sheep's Clothing: Toward Understanding the Composition of the Life of Alexander Nevskii
}

\author{
Donald Ostrowski \\ Harvard University Extension School \\ don@wjh.harvard.edu
}

\begin{abstract}
The Life of Alexander Nevskii is written in two styles: a hagiographic style and a secular style. Scholarly views are divided over whether the Life was written by one person in two different styles or by two persons, either a hagiographic writer and secular editor or a secular writer and hagiographic editor. The present article hypothesizes that the Life was probably written initially in a secular style as a military tale (the "wolf") in the second half of the thirteenth century. This Tale was the foundational layer for the subsequent writing of the Life. Some time later, probably in the second half of the fourteenth century (before 1377), an ecclesiastical redactor edited the text adding phrases in a hagiographic style (the "sheep's clothing"), thus creating a chronicle tale about the life of Alexander Nevskii. In the second half of the fifteenth century, a further editing took place as anti-Tatar interpolations were added, thus creating the First Redaction of the Life of Alexander Nevskii. Following a text critical analysis, this article reconstructs the First Redaction of the Life, in which the two styles are delineated. Then the article provides a translation into English of the hypothetical version of the non-extant military tale about Alexander Nevskii.
\end{abstract}

Keywords

Alexander Nevskii, military tale, saint's life, hagiography, reconstruction, textual criticism

A number of investigators have pointed out that the Life of Alexander Nevskii juxtaposes hagiographic and secular elements. They have, however, interpreted that combination in different ways in regard both to the authorship question and to how the Life was composed. 
In the following article, I present my own hypothesis that the composition represented a three-step process. My goal is to shed light on the origins of this singular literary composition. It seems to me that a complete secular military tale was written in the second half of the thirteenth century as a celebratory exposition of Alexander's military achievements and glory (the "wolf" of the title of this article). Then, some time later, perhaps in the second half of the fourteenth century (before 1377) an attempt was made to transform that secular military tale into a saint's tale (повесть о зэитии) by adding pious sentiments and religious topoi (the "sheep's clothing"). Only in the second half of the fifteenth century was the final form of the text we know as the First Redaction of the Life completed with the addition of anti-Tatar interpolations.

In 1915, Nikolai Serebrianskii proposed that the Life was written by "a younger contemporary of the prince, a monk of the Rozhdestvenskii monastery" and that it "was written not for placement in a chronicle but for church use." Thus, he sees the hagiographic elements as preceding many of the secular elements added later, such as the sections pertaining to the six brave men at the battle on the Neva and the khan of the Eastern Country. ${ }^{1}$ In 1968, Norman Ingham described in some detail the relationship of the styles; namely, that, although the framing of the text is hagiographic, the middle parts "are distinctly secular in substance and style." The military events are told as they would be in a military tale but with a "few pious" sentiments subjoined. Like Serebrianskii, Ingham deemed it probable that the author was a monk. In contradistinction to Serebrianskii, Ingham thought this same monk adopted a standard style for describing military matters and did not need to borrow from a secular work or have it added by someone else. Thus, the author, according to Ingham, wrote the Life in two distinct styles. ${ }^{2}$

In 1974, John Fennell also detected two styles in the Life: "the hagiographical passages are distinct from the annalistic episodes, but sometimes religious sentiments are tacked on to purely military clichés." ${ }^{3}$ The first example he cited of this adding on of "religious sentiments" is the description of

1 N[ikolai] Serebrianskii, Drevne-russkie kniazheskie zhitiia. Obzor redaktsii i teksty (Moscow: Sinodal'naia tipografiia, 1915), 178-180.

2 Norman Ingham, "The Limits of Secular Biography in Medieval Slavic Literature, Particularly Old Russian," in American Contributions to the Sixth International Congress of Slavists, Prague, 1968, August 7-13, 2 vols., edited by William E. Harkins (The Hague: Mouton, 1968) 1: 193-194.

3 John Fennell, "Literature of the Tatar Period (13th-15th Centuries)," in John Fennell and Anthony Stokes, Early Russian Literature (London: Faber and Faber, 1974), 113. 
Alexander's "returning victorious (vozvratisya s pobedoyu)" after the battle on the Neva-the author of the Life tacks on the phrase "praising and glorifying the name of his Creator." ${ }^{4}$ The second example Fennell cited is Alexander's treatment of the enemy after he razed the fortress that the Livonian knights had built "on Alexander's land": "some he killed, others he took with him, and others he pardoned and let go." The author of the Life adds, "for he was merciful beyond measure." 5 Also, like Ingham, Fennell thought this was the work of only one individual, "a cleric" who could write in both the style of hagiography and in the style of the chronicle military tale. ${ }^{6}$ Yet, Fennell implies this may have been a two-step process with the adding-on of pious sentiments to a secular text occurring within an overall hagiographic framework. Fennell pointed to the entry in the Povest' vremennykh let (PVL) for 1019 and the "Paroemia" of Boris and Gleb, both of which texts describe the Al'ta battle of 1019, as a possible model for the secular parts of the Life. ${ }^{7}$

Also in 1974, Serge A. Zenkovsky, like Serebrianskii but in contrast to Ingham and Fennell, attributed the two styles to different individuals. Yet he reversed Serebrianskii's order of stylistic composition; namely, a secular author, who was a "feudal warrior," and a later redactor, who was "some ecclesiastic from the city of Vladimir." For his determination that a military tale written by a warrior is at the core of the Life, Zenkovsky cited three pieces of evidence: (1) the title, "Tale of the Life and Courage of Prince Alexander," is uncommon for a saint's life; (2) the author's reflection on the demise of Alexander- "A man may leave the house of his father but he cannot leave the house of his good lord; and if he has to, he should share the coffin with him"-is befitting of someone who owed secular allegiance to Alexander; and (3) the description by the author of the particulars of the deeds of those in Alexander's army shows that whoever wrote the Tale "[p]robably... knew many of the prince's warriors...." The redactor, in Zenkovsky's view, inserted quotations from and allusions to the Bible while altering the

4 Iu. K. Begunov, Pamiatnik russkoi literatury XIII veka "Slovo o pogibeli Russkoi zemli” (Moscow: Nauka, 1965), 168.

5 Begunov, Pamiatnik, 169.

6 Fennell, "Literature of the Tatar Period," 110-111.

7 Fennell, "Literature of the Tatar Period," 113. Vilho Mansikka and S. A. Bugoslavskii had previously mentioned this possibility. Vilho Mansikka, "Zhitie Aleksandra Nevskogo (Razbor redaktsii i teksty)," Pamiatniki drevnei pis'mennosti, 180 (St. Petersburg, 1913), 43; S. A. Bugoslavskii, "K voprosu o pervonachal'nom tekste zhitiia vel. kn. Aleksandra Nevskogo," Izvestiia Otdeleniia russkogo iazyka $i$ slovesnosti Imperatorskoi Akademii nauk, 19 (1915): 277. 
"narrative and stylistic unity" and rearranging things in an unsystematic manner. ${ }^{8}$

In 1979, A. D. Stokes, after discussing the arguments for and aginst their being genre of military tales in early Rus', proposed that the Life of Alexander Nevskii had been originally written as a military tale that is no longer extant. According to Stokes, military tales may not have conveyed "a religious message." Once, however, the land of Rus' fully adopted Orthodoxy, "the defenders of Rus' became also defenders of the faith, their martial exploits could acquire a religious significance." $\mathrm{He}$ hypothesized that military tales "that praised the exploits of long-dead heroes in long forgotten struggles would hardly have been of interest to later copyists" so they modified them for "contemporary purposes." As a result, in his view, no pure military tale is extant, but they exist in "adapted "adulterated" form in which "it is difficult now to discern the true nature of the genre behind layers of later accretions."

In the present article, I take further Stokes' proposal that the Life of Alexander Nevskii developed from a military tale by attempting to reconstruct that no-longer-extant version of the tale. In contrast to the example of the Tale of the Destruction of Riazan', which Likhachev, Fennell, and Stokes saw developing from a bare chronicle account to military tale to a religious tale, I propose that the military tale was used as the basis for the chronicle tale about the saintliness of the life of Alexander Nevskii. The chronicle tale was later modified into the First Redaction of the Life. In addition, I incorporate Zenkovsky's suggestion that a secular author and a subsequent ecclesiastical redactor were responsible for the composition of the work we know as the Life of Alexander Nevskii. In doing so, I am not denying the possibility that one

8 Serge A. Zenkovsky, ed., Medieval Russia's Epics, Chronicles, and Tales, revised and enlarged edition (New York: E. P. Dutton, 1974), 224-225.

9 A. D. Stokes, "What Is a Voinskaia Povest'?," Canadian-American Slavic Studies 13, nos. 1-2 (1979): 50.

10 Stokes, "What Is a Voinskaia Povest'?," 51. Likhachev provides the developmental stages of the Tale about the Destruction of Riazan' in Voinskie povesti drevnei Rusi, ed. V. P. Adrianova-Peretts (Moscow: Akademiia nauk SSSR, 1949), 123-142; D. S. Likhachev, "Lituraturnaia sud'ba 'Povesti o razorenii Riazani Batyem'," Issledovaniia $i$ materialy po drevnerusskoi literatue, ed. V. D. Kuz'mina (Moscow: Akademiia nauk SSSR, 1961), 9-22; and D. S. Likhachev, "K istorii slozheniia 'Povesti o razorenii Riazani Batyem'," Arkheograficheskii sbornik za 1962 god (K 70-letiiu akademika M. N. Tikhomirova) (Moscow: Akademiia nauk SSSR, 1963), 48-51. Cf. John Fennell, "'Military Tales' of the Thirteenth and Fourteenth Centuries," in Fennell and Stokes, Early Russian Literature, 88-96. 
writer-whether secular or ecclesiastic - could write in both secular and hagiographic styles. I am saying, however, that, in this particular case, the circumstance that the secular passages together form a coherent unity (see below), the positioning and wording of the pious sentiments in an awkward manner in relation to the secular passages, and certain structural peculiarities of the Life tend to corroborate Zenkovsky's hypothesis of a secular author and ecclesiastical redactor. I have argued elsewhere that the author wrote a secular tale sometime between 1263 (the year of death of Alexander) and the 1290s when the author would have been in his 50s (if one supposes he had been a young man in his $20 \mathrm{~s}$ in the 1260s). I based this age estimate on the opening lines of the Tale concerning how he had been an eyewitness, while growing up, to some of the events he describes and that he obtained other information about Alexander from "my fathers" ("отъ отець своихъ"). ${ }^{11}$ The author also claims that he heard about the details of the Battle on the Neva "from my Lord the Grand Prince Alexander and from others who at that time took part in that battle."

Fennell cited of two pious motif interpolations, but one can ask how many more of the pious expressions were added during the process of redacting the Tale into the Life. My resulting hypothetical reconstructions (see appendices A and B) are an experiment in progress. I wanted to see how much of the religious wording and other interpolations of the Life it was possible to eliminate and still have a text that made sense. Somewhat surprisingly, I found that all the religious components could be dispensed with and a coherent narrative remain. Whether the original military tale about Alexander Nevskii had no, a few, or many religious components I cannot say. Some scholars may consider this exercise to be pointless, for they may, as Ingham and Fennell did, see only one author of the Life, which was written then as a complete work at one time (although Fennell does seem to imply a kind of two-step process could have been involved). Other scholars may agree that two individuals-an author of the core military tale and a redactor who added hagiographic phrases-are involved but are unwilling to accept that the military tale was written without any expression of pious sentiments. They are welcome to add back religious components as they see fit, but I hope that, when doing so, they will provide reasons for what they are restoring.

11 See my "Redating the Life of Alexander Nevskii," in Rude \& Barbarous Kingdom Revisited: Essays in Russian History and Culture in Honor of Robert O. Crummey, edited by Chester Dunning, Russell E. Martin, and Daniel Rowland (Bloomington, IN: Slavica, 2008), 23-39. 
The First Redaction of the Life is extant in full or in part in 13 MS copies (one of which dates to 1377, two of which date to the second half of the fifteenth century, seven to the sixteenth century, and three to the seventeenth century). The MSS that contain the First Redaction of the Life are listed here in alphabetical order according to the sigla that Begunov assigned them: ${ }^{12}$

- $A=$ RGB, sobranie Moskovskoi dukhovnoi akademii, fond 173, № 208 [ca. 1550];

- $A p=$ GAAO, sobranie rukopisnykh knig, № 18 [1550-1575];

- $B$ = GIM, sobranie E. V. Barsova, Ne 1413 [ca. 1600];

- $B=$ RGB, sobranie Iosifo-Volokolamskogo monastyria, fond 113, Ne 523 [1550-1575];

- $\pi$ = IRLI, R. IV, op. 24, № 26 [ca. 1550];

$-J_{B}=$ RNB, F. IV. № 2, fols. 168-169 ${ }^{\mathrm{v}}$ [1377] (first part only); ${ }^{13}$

- $M=$ GIM, Muzeiskoe sobranie, № 1706 [1550-1575];

- $O=$ RGB, sobranie A. N. Ovchinnikova, fond 209, № 281 [ca. 1650];

- $\Pi=$ GAPO, sobranie Pskovo-Pecherskogo monastyria, fond 449, № 60 [1450-1475] (beginning and end only);

- $\Pi_{\imath}=$ RNB, sobranie M. P. Pogodina, № 641 [1550-1575];

$-\Pi_{c}=$ GIM, Sinodal'noe sobranie, № 154 , fols. $156-162^{\mathrm{v}}$ [end of $15^{\text {th }}$ century] ${ }^{14}$

- $P=$ RGB, sobranie Olonetskoi seminarii, fond 212, № 15 [1625-1650];

- $\mathrm{Y}=$ GIM, sobranie A. S. Uvarova, № 279 [1650-1675].

Five versions of the First Redaction of the Life of Alexander Nevskii have been published. ${ }^{15}$ In 1882, Archimandrite Leonid (L. A. Kavelin) published the Life from the MS. Moscow Ecclesiastical Academy (MDA), no. 208

12 Begunov, Pamiatnik, 16-17, 159, and “Arkheograficheskii obzor," 195-212.

13 Laurentian Chronicle. For the best publication, see PSRL, vol. 1, $2^{\text {nd }}$ ed. (Leningrad: Akademiia nauk SSSR, 1926), vyp. 1: cols. 477-481; reprint edition in PSRL, vol. 1 (Moscow: Iazyki russkoi kul'tury, 2001).

14 Synod copy of Pskov II Chronicle. For the best publication, see Pskovskie letopisi, 2 vols., ed. A. N. Nasonov (Moscow: Akademiia nauk SSSR, 1940, 1955), 2: 11-16; reprint edition in PSRL, vols. 4-5 (Moscow: Iazyki russkoi kul'tury, 2000).

15 For a list, see Iu. K. Begunov, "K voprosu ob izucheniia Zhitiia Aleksandra Nevskogo,” TODRL 17 (1962): 348-349. 
(A). ${ }^{16}$ In 1913, Vilho Mansikka also published the Life from $A .{ }^{17}$ Neither Leonid nor Mansikka provided a critical apparatus of readings from other copies. In 1915, Serebrianskii published $\Pi$ and $P$ in parallel columns with variants from $A .{ }^{18}$

Also in 1915, S. A. Bugoslavskii, in a review of Mansikka's book provided the first publication of the Life with a critical apparatus of readings from multiple copies. ${ }^{19}$ Bugoslavskii used Mansikka's diplomatic edition of $A$ as his copy text and provided variants from seven copies: $\Pi_{B}, \Pi_{c}$, and $\Pi$ from already published versions; $\Pi_{2}$ from the MS; and $B, P$, and $Y$ from readings for those copies that Mansikka gave in his monograph. Bugoslavskii noted that, because Mansikka did not provide all the readings from $B, P$, and $\mathrm{Y}$, his (Bugoslavskii's) readings from those MSS "are not able to be fully exact." 20 Instead of altering the copy text, Bugoslavskii separately proposed three pages of improvements to it. ${ }^{21}$ In suggesting these improvements, Bugoslavskii depended mainly on agreements of $\pi_{B}$ and $\Pi_{c}$ where $\pi_{B}$ is extant, and on agreements of $\Pi_{c}$ and $\Pi_{2}$ where $\pi_{B}$ is not extant. Begunov was dismissive of Bugoslavskii's publication: "The attempt of S. A. Bugoslavskii at publishing the 'original' redaction of the Life according to the Academy copy (MS. GBL, MDA, № 208, XVI c.) with introduced variants from other copies is hardly able to be considered successful." 22 Furthermore: "The publication of S. A. Bugoslavskii was not exact: the variants are provided from the cited text in Mansikka's monograph and not from the manuscripts." ${ }^{23}$ This criticism is a little harsh since Bugoslavskii acknowledged that the readings for three of the copies he used were incomplete and based on whatever he could glean from Mansikka's comparisons, but the readings for the other four were complete, being based on three published versions and one de visu examination of the MS. For 50 years, until Begunov's editions superceded it in 1965,

\footnotetext{
16 Archimandrite Leonid, Skazanie o podvigakh $i$ zhizni sv. blagovernogo velikogo kniazia Aleksandra Nevskogo, (St. Petersburg, 1882).

17 Vilho Mansikka, "Zhitie Aleksandra Nevskogo (Razbor redaktsii i teksty)," Pamiatniki drevnei pis'mennosti, 180 (St. Petersburg, 1913).

18 Serebrianskii, Drevne-russkie kniazheskie zhitiia, Teksty, 109-120.

19 Bugoslavskii, "K voprosu o pervonachal'nom tekste Zhitiia velikogo kniazia Aleksandra Nevskogo," Izvestiia Otdeleniia russkogo iazyka i slovesnosti Imperatorskoi akademii nauk 19 (1915): 277-289.

20 Bugoslavskii, "K voprosu," 269-270.

21 Bugoslavskii, "K voprosu," 274-276.

22 Begunov, "K voprosu," 349, fn. 5.

23 Begunov, Pamiatnik, 13.
} 
Bugoslavskii's was the best critical edition of the First Redaction available but was rarely cited.

In 1947, V. I. Malyshev published a diplomatic edition of $J$ with facsimiles of the first three folios (fol. 317-318). ${ }^{24}$ In 1965, in an analysis of the relationship of the Slovo o pogibele russkoi zemli to the Life of Alexander Nevskii, the researcher Iu. K. Begunov focused solely on the First Redaction of the Life. In order to depict the relationship of the known-by-that-time 13 copies of the First Redaction, Begunov constructed a three-branch stemma codicum

in which $J_{B}$ occupied its own distinct branch (see figure 1). ${ }^{25}$

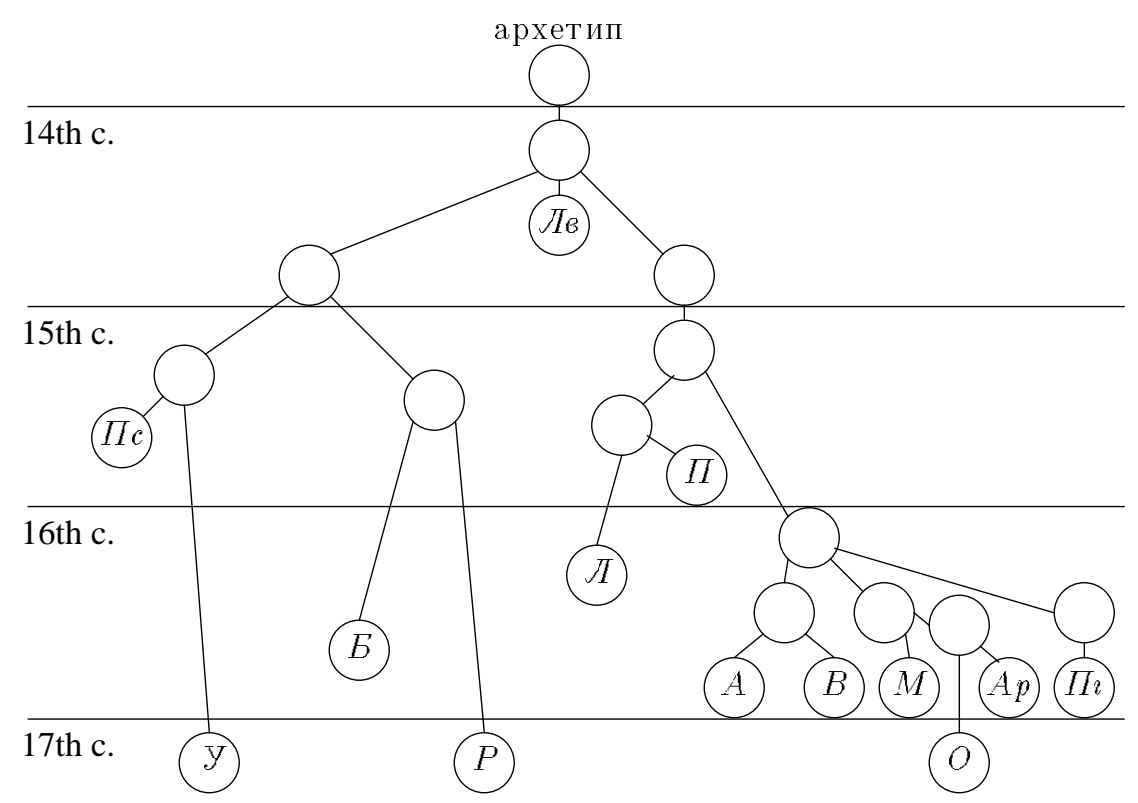

Figure 1 Begunov's stemma for the Life of Alexander Nevskii

The readings of $J_{B}$, thus, should have equal status in determining the archetype with the readings of the common protograph of $E \Pi c P Y$, on one

24 V. I. Malyshev, "Zhitie Aleksandra Nevskogo (Po rukopisi serediny XVI v., Grebenshchikovskoi staroobriadcheskoi obshchiny v g. Rige)," TODRL 5 (1947): 188-193.

25 Begunov, Pamiatnik, 65. 
hand, and $A A p B J M O \Pi \Pi_{2}$, on the other hand. Begunov provided two edited versions of the text of the Life. In the first version, he presented a diplomatic edition of $\Pi c$ with a full critical apparatus containing variant readings from the other $12 \mathrm{MS}$ copies ${ }^{26} \mathrm{He}$ corrected $\Pi_{c}$ only when he thought there was a scribal error in it. In the second version, Begunov "reconstructed" what he considered to be a text closer to the archetype of the Life than any single MS. He used $\Pi c$ as his copy text and provided readings from other MSS only when he changed it. ${ }^{27}$ Begunov did not follow his stemma in his reconstruction of the Life. For example, he added the word "домочадець" after the phrase "Понеже слышах от отець своих" in the introductory paragraph of his reconstruction (187.3), although that word is testified to only by $B$ and $P$. By the rules of stemmatics it could not have been in the archetype for it would require positing an independent dropping of that word in three different places in Begunov's stemma-in $J_{B}$, in the protograph of $\Pi_{c}$ and $\mathrm{Y}$, and in the protograph of the right branch. As a result of this and similar counter-stemmatic changes, ${ }^{28}$ his "reconstruction" turns out to be further from the archetype than his diplomatic edition of $\Pi c .^{29}$

26 Begunov, Pamiatnik, 158-180.

27 Begunov, Pamiatnik, 187-194.

28 See, in particular, adding "бe" in 187.12 on the basis of $У$, adding "же" in 189.55 on the basis of $Б P$, changing "от Немець" to "их" in 190.12 on the basis of MApУ, adding "бяше" in 191.25 on the basis of $Л У$, changing "Господи" to "Боже" in 191.28 on the basis of $E P$, adding " $я$ " in 191.39 on the basis of $Y$, adding "в ризах со кресты" in 191.41-42 on the basis of $Б P У$, changing "их" to "я" in 192.50 on the basis of ЛБРУ, changing "иже бъ ему" to "ему же бъ" in 192.52-53 on the basis of $P$, adding "на мир щедротами" in 192.70-71 on the basis of $E P$, adding "мира" in 192.72 on the basis of $B P$, adding "учитъ" in 192.73 on the basis of $E P$, changing “дивна" to "славна" in 193.75 on the basis of ЛБР, adding "царя" in 193.81 on the basis of $Б P$, adding "господня" in 193.82 on the basis of $B P$, adding “до возшествия нба небеса" in 193.83-84 on the basis of $Б P$, adding "Уже бо не обрящется таковуй князь ни единъ в земли Суждальстей” in 194.83-84 on the basis of $E P$, adding "тяжка" in 194.99 on the basis of $P$, changing " 24 " to "23 день" in 194.3-4 on the basis of ПЛБРУ, changing "хотя" tо "хотеста" in 194.5 on the basis of $P$, adding "Богу же нашему слава, прославльшему святая своя в веки векомъ. Аминь" in 194.8-8 on the basis of ПЛУ.

29 In 1969, Begunov reprinted this version as a plain text in his "Zhitie Aleksandra Nevskogo," on the even-numbered pages in "Izbornik." Sbornik proizvedenii literatury drevnei Rusi, ed. L. A. Dmitriev and D. S. Likhachev (Moscow: Khudozhestvennaia literatura, 1969), 328-343. It has no italics where he had changed his copy text, no footnotes, and no final hard signs on words. A translation into modern Russian appears on 
In 1997, Michele Colucci reassessed Begunov's stemma and, although accepting for the most part the relationship of copies that Begunov proposed, made one major adjustment. Colucci moved $\pi_{B}$ to the right $\left(A A p B I M O \Pi \Pi_{\imath}\right)$ branch of the stemma (see figure 2). Thus, he argued, in effect, that $J_{B}$ should not be given its own equal status with the other two branches in determining primary readings, but that $\pi_{8}$ and $A A p B Л_{1} O \Pi_{2}$ (his $n a t$ ) together determine readings that are equal in status to those of $B \Pi c P Y$ (his $y p$ ). He attributed those cases where the readings of $y p$ agree with $J_{B}$ against those of $A A p B I M O \Pi \Pi=$ to a secondary contaminative influence of $J_{B}$ on $y p \cdot{ }^{30}$ In addition, he attributes the agreements $\Pi$ and $J_{\text {with }} \Pi_{c}$ and $Y$ to a contamination of $n$ on $y$. Colucci pointed out that Begunov did not use his own stemma in reconstructing the text of the Life. ${ }^{31}$ Not using a stemma, even though one was diagrammed, usually with the designation "a schema of the relationship of copies," was typical for Soviet textology, which, following D. S. Likhachev, held that a using a stemma to help determine readings was "mechanistic textology." 32 Colucci also expressed doubt about

the odd-numbered facing pages. In 1981, for the series Pamiatniki literatury drevnei Rusi, V. I. Okhotnikova reprinted Begunov's reconstruction of the text of the First Redaction of the Life from his Pamiatnik with a commentary. "Zhitie Aleksandra Nevskogo, editing, translation, and commentary by V. I. Okhotnikova, in Pamiatniki literatury drevnei Rusi: XIII vek, ed. L. A. Dmitriev and D. S. Likhachev (Moscow: Khudozhestvennaia literatura, 1981), 426-439, 602-606.

30 M. Koluchchi [Michele Colucci], "Pervonachal'naia redaktsiia 'Zhitiia Aleksandra Nevskogo': zametki po istorii teksta," TODRL 50 (1997): 252-260. Colucci's cases of when $\pi_{B}=n a \neq y p$ are $162.8-11,166.92-99,167.42-43,167.45-47,167.51,167.62-63$, and 168.88-92. Of these, all but the first involve a lacuna in the left-branch's $\Pi c$ and $Y$, which presupposes their absent readings had they existed would have agreed with those of $E$ and $P$. Even Colucci's first case is not entirely solid since $O$ of the right branch agrees with $E$ and $P$ of the left. Colucci's cases of when $\pi_{B}=y p \neq n a$ are 160.53, $161.17,161.28,161.51,163.97-100,163.1-2,165.41,165.52$, 166.93, 166.6, 166.12, 167.18, and 168.12. Of these, 166.93, 166.6, 166.12, and 167.18 also involve a lacuna in $\Pi_{c}$ and $\mathrm{Y}$, and 165.52 involves an idiosyncratic reading of $\Pi_{c}$. The idiosyncratic readings of $\pi_{B}$ that Colucci considers to have "real editorial significance" he gives as 166.8-86, 166.1-5, 166.97-99, and 167.25-26. Colucci numbers his cases according to the page number and variant of Begunov's critical edition (Begunov, Pamiatnik, 158-180).

31 Koluchchi, "Pervonachal'naia redaktsiia 'Zhitiia Aleksandra Nevskogo',, 253.

32 See the section titled "Krizis literaturovedcheskoi mekhanicheskoi tekstologii," in D. S. Likhachev, Tekstologiia. Na materiale russkoi literatury X-XVII vv., $1^{\text {st }}$ ed. (Moscow and Leningrad: Akademiia nauk SSSR, 1962), 6-20; $2^{\text {nd }}$ ed. (Leningrad: 
Begunov's use of a "codex interpositus"- that is, a hypothetical intervening copy "between a manuscript (or group of manuscripts) and its protograph" (253). Use of such an intervening copy between the archetype and the readings suggested by the MS copies was also characteristic of Soviet textology. It allowed the modern editor to overrule the testimony of the MS copies by claiming readings for the archetype that were not supported by the MSS.

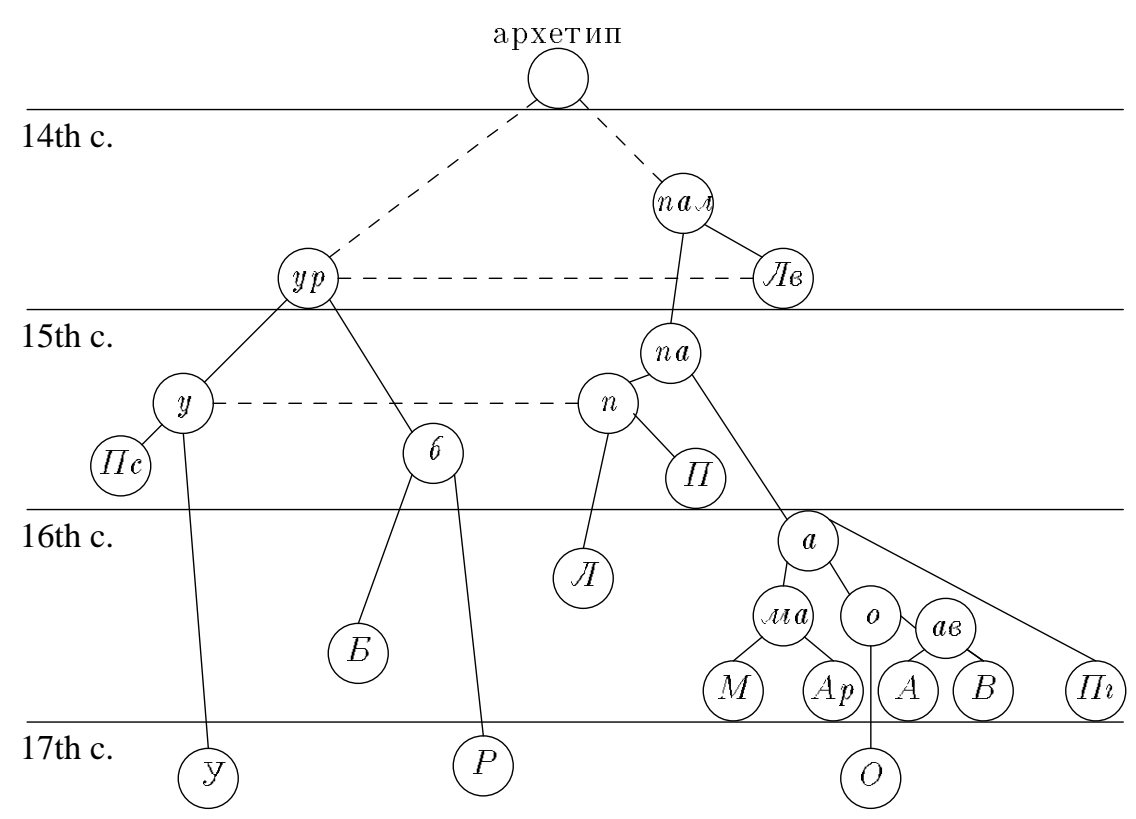

Figure 2 Colucci's stemma for the Life of Alexander Nevskii

Here I will limit myself to discussing briefly how I edited the text and why I chose to place $\pi_{B}$ above the common protograph of all the other copies. In editing a text for publication, an editor has several options, which are dependent on the goal of the edition and on the relationship of the extant manuscripts to each other. As I wrote recently in the journal Kritika:

If one copy is clearly best representative of the archetype or authorial text, then it should be used as the copy text and variants provided from the other copies only to show the history of the development of the text. If no single copy is best and if the manuscript tradition is "open" (i.e., no clear genealogical relationship

Nauka, 1983), 8-24; $3^{\text {rd }}$ ed. (St. Petersburg: Aleteiia, 2001), 14-29. 
can be established among the copies), then picking and choosing readings from different copies based on the knowledge, skill, and intuition of the editor is to be preferred. If the manuscript tradition is "closed" (i.e., a clear genealogical relationship can be determined), then a stemma should be used..$^{33}$

In the case of the First Redaction of the Life of Alexander Nevskii, we have a hybrid situation in regard to the MSS. For the first $44.5 \%$ of the text of the Life, in my opinion, a "best" copy exists in $\pi_{B}$, but the last $55.5 \%$ of the text of the Life is missing in that copy. For the remainder of the text of the Life to the end, a closed tradition exists whereby no one copy is demonstrably better than all the others, although a clear genealogical relationship can be established. Thus, for the last part of the text, I resorted to a stemma to help determine the "best" (i.e., closest to the archetype) reading.

In Appendix A, I present my reconstruction of the First Redaction archetype. For the most part, my reconstruction is similar to the version of the First Redaction that Begunov edited and published in 1965. It differs from his version in two major respects. First, I used $J_{B}$ for the copy text for the first part of the text and resorted to a stemma for the last part, whereas Begunov used $\Pi c$ as his copy text throughout. Second, my understanding of the relationship of the MS copies to each other differs from his (see figure 3). As a result, in particular choice of words and phrases, I accepted the primacy of readings in the MS copies in a different hierarchical order; namely, where $J_{B}$ is extant, I accepted the reading of $J_{B}$ except to correct scribal accidentals; otherwise, I considered $\gamma$ and $\delta$ to be of theoretical equal value in determining $\beta$. In practice, $\delta$ tends to represent $\beta$ more often. As Colucci demonstrated the readings of right-branch MSS are more often closer to $J_{B}$ than are those of leftbranch MSS. The agreements of $J_{B}$ with $n a$ that Colucci sees as placing $J_{B}$ in the right branch of the stemma might better be understood as occurrences of agreements of the right-branch copies with the primary reading of $J_{B}(\alpha)$. Thus, where $J_{B}$ is not extant, I tended to favor the agreements of $\delta$ (agreements of $\Pi_{2}, \pi$, and $\Pi$ ) over $\gamma$ (agreements of $\Pi c, Y, B$, and $P$ ), when the two disagree. Finally, I rarely looked to $I \Pi$ alone or $A A p D M O$, except

33 Review of S. A. Bugoslavskii, Tekstologiia drevnei Rusi, 2 vols., compiled by Iu. A. Artamanov, vol. 1: Povest' vremennykh let, vol. 2: Drevnerusskie literaturnye proizvedeniia o Borise and Glebe, Moscow: Iazyki slavianskikh kul'tur, 2006-2007; A. L. Nikitin, Tekstologiia russkikh letopisei XI-nachala XIV vv., vypusk 1: Kievo-Pecherskoe letopisanie do 1112 goda, Moscow: Minuvshee, 2006; Galitsko-Volynskaia letopis'. Tekst. Kommentarii. Issledovanie, compiled by N. F. Kotliar, V. Iu. Franchuk, and A. G. Plakhonin, under the editorship of N. F. Kotliar, St. Petersburg: Aleteiia, 2005, in Kritika: Explorations in Russian and Eurasian History 9, no. 4 (2008): 940. 
insofar as they agree with $\Pi_{2}$ or are able to correct some scribal accidental in $\Pi_{\text {. }}$. In the case of certain readings, this represents an almost complete reversal of Begunov's hierarchical placement and results in a reconstruction that is closer to the text that would result from Bugoslavskii's proposed improvements than either to Begunov's critical apparatus version or to his reconstruction. I also see contamination of the common protograph $(\theta)$ of $\Pi c$ У on the common protograph $(\varepsilon)$ of $J \Pi$, whereas Colucci saw the contamination going in the opposite direction. Although I agree with Colucci in general terms concerning the dangers of using a codex interpositus, I propose having $\beta$ as in effect an intervening hypothetical copy between the MSS and $\alpha$ is justified here.

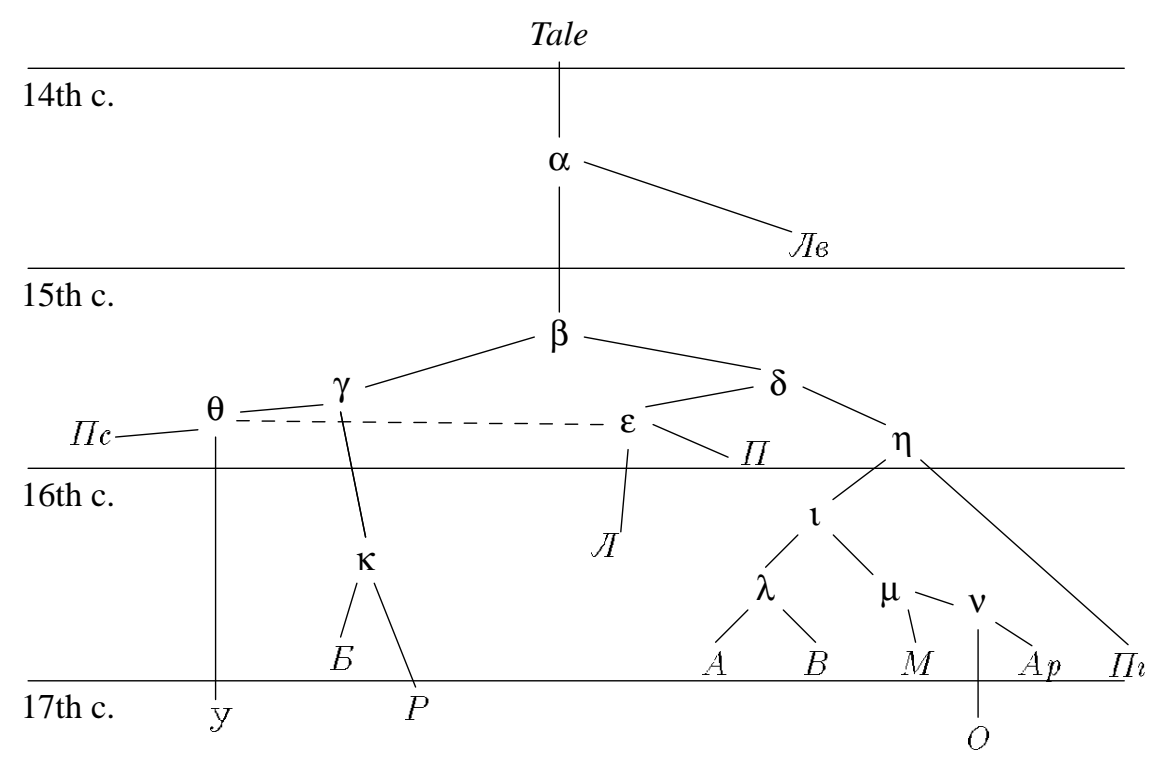

Figure 3 My preferred stemma for the Life of Alexander Nevskii

When turning the military tale into a saint's tale, the fourteenth-century redactor inserted new sections (indicated as the italicized parts in Appendix A). But, even then in the second half of the fifteenth century, three additional sections were interpolated (indicated with the bracketed designations C-1, C-2, and C-3 in Appendix A). Toward the end of the Tale, "a mighty khan of the Eastern Country" summons Alexander to him (section A-1 below). Then Alexander goes to Vladimir with his army. News of his coming reaches the 
mouth of the Volga River, and the Moabite women frighten their children, warning them of Alexander's coming (C-1). He receives the blessing of Metropolitan Kirill to go to the khan (B-1). Alexander goes to the khan who honors him and lets him go (A-2). No explicit description of Alexander's return from the khan is given in the text of the Life at this point, as the reader is left to construe from the ensuing section that he did return. In that section, Khan Batu gets angry at Alexander's brother, Andrei, and sends his general Nevruy to devastate the Suzdalian land (C-2). ${ }^{34}$ Alexander rebuilds the cities and churches and returns the refugees to their homes. From Alexander's rebuilding activities, the reader can suppose that Alexander had returned from his visit to the khan, unless he undertook the rebuilding of Rus' cities and churches from Sarai. A quotation from Isaiah 1: 16, 17, 23 and 56: 1-2 and a peroration about how God had endowed the land "with wealth and glory" follows.

Then the reader is told about the sending of a letter by the Pope to Alexander asking to be allowed to send two cardinals to instruct him in Catholicism, but Alexander turns the request down (B-2). In the next section, "foreign peoples" (inoplemenniki) are violently forcing the Rus' to serve in the ranks of the army, but Alexander goes to the khan and pleads with him not to drive his people into misery (C-3). The description that Alexander "went" (poide) to the khan is another indication in the Life that Alexander had returned from his previous trip. In the next section Alexander sends his son Dmitrii to the Western country, where he conquers some German land and takes the city of Iur'ev returning with prisoners and booty. The Life then abruptly begins to describe Alexander's return from the khan without transition. After the previous section describing Dmitrii's campaign in the Western country, the $\alpha$ reading merely states: "Князь великый Александръ взыде отъ иноплеменникъ” (“Grand Prince Alexander went from the foreign peoples"). $\Pi_{c} B P Y$ attempt to smooth the transition from the previous section by adding the phrase "Отець же его" ("His father") at the beginning of the sentence.

The general assumption among scholars is that transmission of the text of the Life remained stable for almost 200 years after it was first composed, from ca. 1280s to the second half of the fifteenth century and that the First Redaction represents the late thirteenth-century version. Only then did

34 As Zenkovsky pointed out, the campaign of Nevruy against Andrei Iaroslavich occurred under Batu's successor Sartaq. Zenkovsky, Medieval Russia's Epics, Chronicles, and Tales, 233, fn. 27. For an analysis of the chronicle accounts of this campaign, see my “The Tatar Campaign of 1252," Palaeoslavica 17, no. 2 (2009): 46-64. 
transmission become volatile with the text undergoing many changes over the course of the next 100 or so years. I have proposed that the text originally composed in the second half of the thirteenth century underwent a major transformation in the mid to late fourteenth century. What resulted was a sequence of nested insertions within a foundational layer framework; that is, these interpolations may have occurred in the mid to late fifteenth century when the First Redaction was created. I have designated that foundational layer with the letter "A", the first layer of insertions with the letter "B", and the second (later) layer with the letter " $\mathrm{C}$ ".

A-1: The khan summons Alexander

C-1: At the death of his father Iaroslav, Alexander goes to the city of Vladimir and news reaches the mouth of the Volga. Moabite women frighten their children by saying "Alexander the prince is coming."

B-1: Alexander consults with Metropolitan Kirill who gives him his blessing to go.

A-2: Alexander goes to the khan, who renders him honor and lets him go.

C-2: Batu gets angry at Andrei and sends the general Nevruy with an army to ravage the Suzdal' land. Prince Alexander rebuilds the destroyed churches and the cities gathering the home of the people who had fled during the invasion. Quotation from Isaiah.

B-2: The Pope writes to Alexander wanting to send two cardinals to teach him about the Catholic faith, but Alexander turns his request down.

C-3: The foreign people were violent forcing the Rus' to serve in the ranks of the army, but Alexander goes to the Khan and pleads with him not to drive his people into misery.

B-3: Alexander sends his son Dmitrii against the Western land. Dmitrii conquers some of the German land and takes the city of Iur'ev, returning to Novgorod with prisoners and booty.

A-3: Alexander returns from "the foreign people" (“оть иноплеменникъ"), goes to Nizhnii Novgorod, then Gorodets where he falls ill and dies.

Thus, if one reads sections A-1 / A-2 / A-3 one after the other, one has a complete narrative: Alexander is summoned by the khan, he goes to the khan, is 
honored, and returns from the khan. This sequence is what I posit was the way the Tale originally read; that is, the foundational layer. The second (B-1), fourth (B-2), and sixth (B-3) interpolations were most likely added in the fourteenth century (pre-1377) when the military tale was turned into a saint's tale. Thus, one can read the sequence as A-1 / B-1 / A-2 / B-2 / B-3 / A-3 for the sequence as it probably was in the continuation of $J_{B}$. The first (C-1), third (C-2), and the fifth (C-3) interpolations were most likely added in the post-1448 period, when anti-Tatar rhetoric began to pervade Church literature about the steppe people. ${ }^{35}$ That is the sequence of the First Redaction as we now have it.

For the sake of consistency, I normalized the text throughout, which includes standardizing spelling, expanding abbreviations, adding front and back yers after superscript consonants in final position, and inserting modern punctuation. I have not provided variant readings, for which one may consult the diplomatic edition of $\Pi c$ with critical apparatus that Begunov edited and published in 1965. Those parts that I believe were added to the Tale to transform it into a Life are italicized. In Appendix B, I provide an English translation of the non-italicized parts; that is, of the Tale as it may have existed before attempts were made in the fourteenth century to turn the military tale into a saint's tale. Here we see a spare but structurally well-organized Tale with an introduction, in which the "thematic clue" is a story about a brave ruler; in this case, the Emperor Vespasian. Then follow three stories-the first involves a ruler from the Northern Country, the second involves a ruler from the Western Country, the third involves a ruler from the Eastern Country. The Tale closes with Alexander's death and a lament by the author. Into this foundational layer were added religious sentiments, biblical allusions and quotations, and digressive stories in the mid-fourteenth century to make the saint's

35 See my Muscovy and the Mongols, 23, 138-141, 164-247. A case in point is the treatment of Nevruy's campaign in the chronicles. Early chronicles either do not mention it or state that he went against Andrei Iaroslavich and chased him beyond the sea. The Suzdal' Chronicle adds that "the Tatars scattered over the land" (presumably in search of Andrei) and "caused much misery when they left" (presumably because of the many captives, horses, and cattle they took). Later chronicles state that Nevruy went against the Suzdal' land as well. PSRL 1 (2nd ed., 1928), col. 524; 3 (2nd ed., 2000), 304; 6.1 (2nd ed., 2000), col. 327; 7: 159; 10: 138; 42: 118. Cf. John Fennell, "Andrej Jaroslavič and the Struggle for Power in 1252: An Investigation of the Sources," Russia Medievalis 1 (1973): 49-63. 
tale, almost half of which appears in $\pi_{B}$, and then into the First Redaction in the second half of the fifteenth century.

\section{Appendix A}

Житие Александра Невского: Первая редакция (реконструкция)

Того же льта. Преставися великыи князь Александръ сынъ Ярославль. Скажемъ же мужство и житье его. O Господинь наиемь Исусь Христь Сыни Божьи азъ худыи гръиныи недостоиныи начинаю писати житье великого князя Александра сына Ярославля внука Всеволожа понеже слышахъ отъ отець своихъ и самовидець есмъ възрасту его и радъ быхъ исповљдаль святое житье и честное и славное но яко же Приточнися рече «B злохитру дуию не внидеть прилудрость на высокыхъ бо краихъ есть посреди же стезь стояаеть при вратпхь силныхь приспдитьs. ${ }^{36}$ Aие $и$ врубъ есль улоль малитвон святое Госпожи Богородиии посппиенье святаго князя Алехсандра начатокъ положн.

Си бъ князь Александръ Бололь роженъ отъ отца милостилюбиа и мужелюбиа пакы же кроткало князя великого Ярослава и матери святое Федосьи. Яко же реге Исаия пророкъ "Тако в лаголеть Господь: “Князи ази учиняю свяиени бо суть азъ вожю ${ }^{37} q^{\prime \prime}{ }^{38}$ Воистину без Божья бо повелинь не би княженье его. Но и възрастъ его паче иньх человекъ, и глас его-якы труба в народь $и$ жице его-аки пиие Иосифа ${ }^{39}$ иже бл поставиль его Erunemьскыи uесарь втогаго uесаря въ Erunmn. Cuла би его-часть оть силы Салисоя. Даль би елу Богъ премудрость Сололиню и храбрьство же акы цесаря Римьскаго Еспиинана иже бь пльнилъ всю Подъиюдьискую землю и ньгдь исполчися къ граду Атапату приступити и шедше гражане и оувидьша полкъ его, и остася единъ, и, възврати силу ихъ ко вратомъ ко граднымъ, и посмьяся дружинь своеи, и укори я, река: «Оставите мя единого». Такоже и сии князь Александръ бь побьжая а не побьдимъ.

36 Cf. Wisdom 1: 4; Proverbs 8: 2-3.

37 азъ вожю changed from а ввожю in $\pi_{в}$.

38 Cf. Isaiah 13: 3.

39 Иосифа changed from Есива in Лв. 
И сего ради нькто силенъ отъ Западныя страны иже нарицаяся слугы ${ }^{40}$ Божья отъ тьхъ приде, хотя видьти дивныи то взрастъ его яко же древле иесаря Ужская приходъ $к$ Сололону хотяии слыиати прелудрость езо. Такоже и се именемь Андрьяшь, видьвъ князь Александръ возвратися к своимъ и рече: «Прошедъ страны, и языки, не видьхъ таковаго и въ цесаря ни въ князихъ князя».

Се же слышавъ, король части Римьское отъ полунощныя страны, такое мужство князя Александра и помысли в собь: «Да поиду пльню землю Александрову». И собра силу велью наполни корабля многы полковъ своих подвижеся в силь тажць исполнися духымь ратным. И приде в рьку Неву шатася безумьемъ, посла слы загордевъся ко князю Александру в Новъгородъ рече: «Аще можеши противитися мнь то се есмъ здь уже пльню твою».

Александръ же, слышавъ словеса ихъ, разгорься сердцемь $u$ вниде в иерков святыя Софья, падъ на кольну пред олтареиъ, нача лолитися со слезали: «Боже хвалныи, и праведныи Боже великыи и крипкыи Боже превпчныи создавыи небо и зелилю $и$ постави предилы язкол и повели жити не престуная в чюжю частьs. ${ }^{41}$ И въсприияъ псалиъную пьснь рече: "Суди, Господи, обидящия мая възбрани бортоцился со мною, приили оружье и иить стани в полощь мния. ${ }^{42}$ Скончавъ молитву вставъ поклонися архиепископу. Архиепископъ же Спиридонъ благослевеси его и отпусти. Он же выиде изъ иеркве утирая слезы, и нача крипити дружину свою, и рече: "Не в силахъ Богъ но в правди. Полянель Пвснословиа "Си во оружьи си на конех мы же во илия Господа Бога наиало призовели ти спяти быиа и падоиа мы же встахол прости быхолъ" ". 43 И си рекъ поиде на ны в маль дружинь, не сождавъся со мною силою своею, но уповая на святыю Троиию.

Жалостно же и слышати яко отець его, честныи Ярославъ великыи не бь вьдалъ такого встанья на сына своего, милого Александра, ни оному бысть послати когда вьсть къ отцю: еже бо ратнии приближишася. Тьмже мнози Новгородци не

40 слугы added.

41 Deuteronomy 32: 8; $2^{\text {nd }}$ Kings 19: 15.

42 Psalms 34: 1-2.

43 Psalms 19: 8-9. 
совокупилися бьша понеже ускори князь поити.

II прииде на ны въ день вскресенья, на палать святыхь отеиь 600 и 30 бывииа збора в Халкидонь и святоно мученику Кгорика и Улиты и святого князя Володилера крестивиаго Русскую зелию илияие же виру велику к тьла мученикола Бориса и Глиба.

И бв некто мужь старьииина в землии Ижерскои ${ }^{44}$ иленемь Пелуги поручено же бысть елу стража морьская. Bсприят же святое крещенье и живяие посреди роду своего погана суиа. И наречно бысть ила его в святыль крецении филипъ. Живяие богугодно в среду и в пяток пребывая въ алибл. Тилже сподоби его Богъ видити видинье страино во тъ день. И скажеми вкратияв.

Увидъиа силу ратныхъ, иде противу князя Александра, да скажеть елу станы и обрытья ихъ. Стояию же ему при краи моря, стрежаиет обон пути, и пребысть всн нощ во бдиньи. Якоже нача всходити солние и слыиа июль страиенъ по лор ю и види насадъ единъ гребущь, посреди насада стояща мученику Бориса и Глиба въ одежахъ червленыхъ, и биста руии держаста на рали гребии же спдаху аки милою одини. II рече Борисъ: «Брате Глибе, повели грести да положель сроднику своему Александру видввъ же таковое видинье и слыиа таковыи зиась оть мученику, стояаеть трепетенъ, дондеже насадъ очью его.

Потоль скоро привха князь Александръ, онъ же видввъ князя Александра радостныма очима исповлда ели единолуу. Князь же рече: "Сезо не рии николуу.

Оттоль потщавъся наьха на нь въ 6 чась дне [в льто 6748]. ${ }^{45}$ Бысть сьча велика надъ Римляны, и изби множество бесчислено ихъ и самомы королеви взложи печать на це острымъ своимъ копьемь.

Здь же явишася 6 мужь храбрыхъ [с самьмъ с нимъ ис полку его]. ${ }^{46}$

Единъ именемь Гаврило Алексичь сеи ${ }^{47}$ наьха на шнеку

44 Corrected from Жжерскои.

45 Bracketed words are not in $A A p Б B \pi M O \Pi_{\imath} \Pi_{c} P У$. $Л \Pi_{\imath}$ read: ce же бысть в лето 6745 .

46 Bracketed words are unique to $\mathbb{Л}_{в}$. Others have: иже $\left[\Pi_{\imath}:\right.$ и] мужьствоваша [ $\Pi_{2}:$ мужествовавше; ААрMO: мужьствовав; $B:$ мужествовал] с нимъ [ЛП : ними; $A B:$ им] крьпко. 
видъвъ королевича мча под руку и възъьха по досць и до самогу коробля по неи же хожаху с королевичемь иже текоша передъ нимъ а самого емше свергоша и с конемъ в воду ${ }^{48}$ доскы и Божъею милостью невреженъ ${ }^{49}$ бысть и паки наБха, и бися с самьмъ воеводою середи полку ихъ.

2 именемь Сбыславъ Якуновичь Новгородець, сеи ${ }^{50}$ наьха многажды на полкъ ихъ и бьяшется единьмъ топоромъ не имья страха въ души своеи. И паде ньколико отъ руку его и подивишася силь и храбръству его.

3-и Яковъ родомъ Полочанинъ ловчии бь у князя. Сеи ${ }^{51}$ нађха на полкъ с мечемъ и похвали его князь.

4 Новгородець именемь Мьша. Сеи ${ }^{52}$ пьшь натече на корабли и погуби. 3 корабли з дружиною своею.

5-и Отъ молодыхъ его именемь Сава. Сеи ${ }^{53}$ въьха $^{54}$ в шатеръ великии, королевъ золотоверхии и подъсьче столпъ шатерныи. Полци Александрови, видьвше шатра паденье възрадовашася.

6-и Отъ слугъ его именемь Ратмьръ. Сеи 55 бися пьшь и оступиша и мнози. Онъ же отъ многыхъ ранъ паде и тако скончася. Си же вся слышахъ отъ господина своего великого князя Александра и отъ иньхъ, иже в то время обрьтошася в тои сьчи.

Бысть же в товреля чюдо дивно, яко же во древьняя дни при Езекии иесари, еда приде Сенахиримъ, Асуриискыи, иесарь на Иерусалель хотя пльнити ${ }^{56}$ радъ святыи Ерусалемъ внезапу изиде анвель Господинь изби и оть полка Асурииска 185 тысяаиь. II въставие утро, обритоиася трупья мертвы вся. Такоже басть при побиди Александрови, егда поблди кородя объ онъ поль рикы Ижжеръ, иде же не би проходно полку Александрову. Зди

\footnotetext{
47 ceи changed from ce in $\pi_{B}$.

48 ААрВЛМОПъ: море; БР: Неву; ППсУ: lacuna.

49 Corrected from невренъ in $\mathbb{J}_{B}$.

50 сеи changed from ce in $\pi_{B}$.

51 Сеи changed from $\mathrm{Ce}$ in $\mathbb{M}_{B}$.

52 Сеи changed from $\mathrm{Ce}$ in $\mathbb{J}_{B}$.

53 Сеи changed from $\mathrm{Ce}$ in $\mathbb{A}_{B}$.

54 Corrected from Bъxa

55 Сеи changed from $\mathrm{Ce}$ in $\mathbb{A}_{B}$.

56 пльнити changed from пьнити in $Л_{B}$.
} 
обритоииа много множество избъеныхъ оть анвела Господиня. И останокъ побъже трупья мертвыхь своихъ налетаиа корабля истопоиа корабля в мори. Князь же Александръ възвратииася $c$ побпдог, твала и слава иля своего твориа Отиа и Сына и Cватого Духа.

Въ 2-е же льто по возвращении с побьдою князя Александрандра, пакы придоша отъ западныя страны и възградиша ${ }^{57}$ градъ въ отечьствь Александровь. Князь же Александръ изыде на ня воскоре и изверже градъ ихъ из основанииа, а самехъ извьша иньхъ с собою приведе, а инъхъ, полилова, отпусти: бл бо милостивъ паче миры.

По побьдь же Александровь, яко побьди короля, в третии годъ, в зимнее время, поиде на землю немецкую в силь велиць, да не хвалятся, ркуще: «Укоримъ Словеньскыи языкъ ниже себе».

Уже бо бяше взять градъ Псковъ, и тиуны у нихъ посажени. Техъ же князь Александр изыма и градъ Псковъ свободи отъ плена. А землю ихъ повоева и пожже и полона взя бес числа, а овьхъ иххече. Оне же, из городъ, совокупишася и рьша: «Поидемъ побьдимъ Александра и имемъ его рукама». Егда приближишасая, и почютиша стражие. Князь же Александръ оплъчился и поидоша противу себе, и наступиша море Чюдьское обоихъ множества. Отець же его Ярославъ послалъ бь ему на помощь брата меньшаго Андрья въ мнозе храбрыхъ, яко же древле у иаря Давыда силнии, крипиии. Тако и млужи Александровы исполнииася духа ратна: бяху бо сердиа ихъ, акы лволь, и риия: "О княже наиь драяыи! Ныни приспв вриля наль положити члавы своя за тя». Князь же Александро, воздивъ руип на небо, и рече: “Суди, Боже, и разсуди прю мою отъ языка велерична и полози ми, Боже, яко же древле Моисвови на Алиалика и прадлду моему Ярославу на окааннаго CBяmonoskas ${ }^{58}$

Бл же тогда день суботныи, въсходясю солнию,

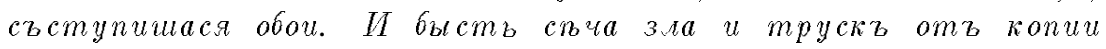
домденииа и звукъ отъ мечнаго спченииа, яко же миорю полерзъию двиянутися; не би видити леду; покры бо сякровию.

57 възгра changed to възградиша in $\mathbb{J}_{B}$. End of $\mathbb{M}_{B}$.

58 Cf. Exodus 6: 26; Psalms 34: 1-2. 
Си же слынахъ отъ саловидиа, иже рече мии, яко видихъ полкъ Божии на въздусь, прииедии на полощь Александрови. И побпди я полоцин Божею, и даия патнии плеци своя $и$ спчахуть я, гоняще, яко по аеру, и не би кало утещи. Зде же прослви Богъ Александра предъ всили полкы, яко Исуса Наввина у Ерехона. А иже рече: “Илели Александра рукала», сего дасть ему Богъ в руив езо. И не обритеся противникъ ему въ брани никовда же. Возвратися князь Александръ с побьдою славною. Бяше множество полону в полку его, ведяхуть босы подле конии, иже именуются рыдали.

И яко же приближися князь къ граду Пскову, ияулени же и nonoвe и весь народъ срьтоша предъ градомъ, подающе $x в \boldsymbol{a} y$ Богов $u$ славу господину князю Александру, поюще пьснь: "Пособивыи, господи, кротколиу Давыду побидити иноплеменьникы $и$ влрнолу князо наиелу оружиемь крестнымъ свободити врадъ Плесковъ оть иноязиникъ рукою Александровоюь.

«O, невњ ласи плесковичи! Aще се забудете и до правнучатъ Александровыхъ, уподобитеся Жидоль, ихъ же препита господьв пустыни манною и крастелми печеными, и сихъ всвхъ забыиа Бога своего, изведииаго я изъ работы Eзипетьскыяљ.

И нача слыти имя его по свьмь странамъ и до моря Египетьскаго, и до горъ Араратьскыхъ, и обону страну моря Варяжьскаго, и до великаго Рима.

В то же время умножися языкъ Литовьскии и начаша пакостити волости Александровь. Онъ же, выездя, и нача избивати я. Единою клютися ему выехати, и побьди 7 ратии единьмъ выездомъ, множество князеи ихъ ихби, а овьхъ рукама изыма; слугы же его, ругающеся, вязахуть я къ хвостомъ конеи своихъ. И начаша блюстися имени его.

[A-1] В то же время некто царь силенъ на Въсточньи

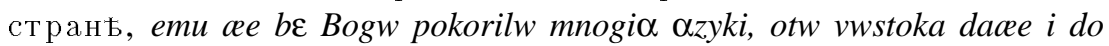
zapada. Тъи же царь, слышавъ Александра тако славна и храбра, посла к нему послы и рече: «Александре, вьси ли, яко Богъ покори ми многыя языки. Ты ли единъ не хощеши покороитеся силе моеи? Но аще хощеши съблюсти землю свою, то скоро прииди къ мнь, и да узриши честь царства моего».

[C-1] Князь же Александро прииде во Володилеръ по улертвии отиа своего в силь велиия. И бысть зрозенъ приездъ его, $и$ пролчеся висть и до усть Волиы. И начаиа жены 
моавитьскыя полоиати дити своя, рекуще: «Александръ едетъ!»

[B-1] Съдумавъ же князь Александръ, и благослови его enuскопъ Кирилъ, и поиде к цареви.

[A-2] И видьвъ его царь Батыи, и подивися, и рече велможамъ своимъ: «Воистинну ми поведаша, яко ньсть подобна сему князя». Почьстивъ же и честно, отпусти и.

[C-2] II потоль же разинвася иарь Батыи на брата его, лиениаго Андрия, и посла воеводу своего Невруя повоева зелию Суждальскую. По плинении же Невыеве князь великыи Александръ иеркви въздвиянувъ, градь испоцьнивъ, дюди распуженыа събра в долы своя. О таковыхъ бо рече Исаиа пророкъ: «Кназь благъ въ странахъ - тихъ, увитливъ, кротокъ, съмиярень - по образу Божию естьs, 59 не внилая богатьства не презря крови праведничю, сироть и вдоиии въ правду судя, милостилюбеиь, блань долочадиель своиль и вънииниль оть странъ приходяииль корлитекъ. На таковыя Богъ призираетъ: Бог бо не аленоль любить, но человеколи си щедря ущедряеть и показаетъ на лирь лилость свою. Распострани же Бов зелию его болатьстволь и славою, и удоцъжи Бовъ лита елиу.

[B-2] Никовда же приидоиа къ нелиу послы отъ папы, из великого Рила, ркуще: «Папа наиъ тако влаголетъ: “Слыиахоль тя князя честна и дивна, и земдя твоя велика. Сего ради послахоль $к$ тоби оть двоннадесать кординалу два хытреиа - Азалда да и Гьлонта, да послуиаеии учения ихъ о закони Божии” ж. Князь же Александръ, здумавъ съ мудреии своими, въсписа $\kappa$ нему и рече: «Omъ Aдама до nomona, omъ nатопа до раздедения языкъ, до начяла Авраалыя, отъ Авраала до проитиа Иисраияя сквозе Терлное море, отъ исхода сыновъ Иисраилевъ до улертвия Давыда иаря, отъ начала иарствия Сололиоя до Августа и до Христова рожества, отъ рожеств Христова до страсти и воскресения господня, отъ въскресения же его и до возиествия на небеца, отъ възиествиа на небеса до иарства Константинова, отъ начала иарства Костянтинова до перваго собора, отъ перваго собора до седмаго - си вся добри съвидаели, а отъ васъ учения не приилаемъж. Они же възвратииася въсвояси. И улножииася дни живота его. Би бо иервелюбець и мьнихолюбеиь и нищая любя, митрополита же и

59 Cf. Isaiah 1: 16, 17, 23; 56: 1-2. 
епископы чтяяие и аки салого твориа.

[C-3] Би же толда нужда велика оть поганыхъ: гоняхутъ христиань, ведяще с собон воиньствовати. Князь же великыи А лександръ поиде к иареви, давы отлолил кюдии отъ бъды.

[B-3] А сына своего Д иитрия посла на Западныя страны, и вся полькы своя посла с ниль, и ближнихъ своихъ долочадеиь, рекии к нимъ: "Служите сынови моелу, акы салолуу мни, вспли животоли своилия. Поиде Ярославъ с сыновьцили

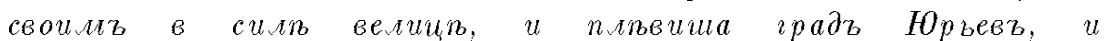
възвратииася въсвояси съ мновыль полоноли и с великон честью.

[A-3] Князь великыи Александръ взыде отъ иноплеменникъ и доеди Новагорода Нижняго и ту пребывъ мало здравъ, дошедъ Городца, разболься.

O, горь тобь, бьдныи человече! Како можеши написати кончину господина своего! Как не испадета ти зьници вкупь съ слезами! Како же не урвется сердце горкыя тугы! Отца бо человекъ можетъ, а добра господина не мощно оставити: аще бы лзь, и въ гробъ бы льзлъ с нимъ!

Пострада же Бовов крипко, остави же земное царство и басть мнихъ: бл бо желание его паче мири агиельскало образа. Сподоби же его Богъ болиии чинъ приати - скиму. И тако Господеви духъ свои предасть, с мироль месяца ноября въ 14 день, на палиять сватого апостола Фuлипnа.

Mumponолитъ же Кириль влаголаие: «Тада моя, разульите, яко уже заиде солние земли Суздальскои! Иерьи и диакони, черноризињ, нищии и богатии, и вси людие глагодааху: «Уе погыбаеми!».

Cвятое же тило его понесойа къ зраду Bолодилерю. Mumponолитъ же князи и бояре, и весь народъ, малии и велииии, сритоииа и въ Боголюбивљль съ сввщали и с кандилы. Народи же съгнатахутся, тотяие прикоснутися честниль одри святого тила его. Бысть же вопль и кричание, и туга, яко же нисть была, тако, я и зелии потрястися. Положено же бысть твло ево въ Рожестве святыя Богородица, въ архимандритьи велиции, месяиа ноября въ 24, на палять святого отиа A мифилохия

Бысть же товда чюдо дивно и памити достоино. Езда убо положено бысть святое тьло его в раку, тогда Савастиянь иконоль и Кирићъ митрополитъ хотя посъяти ему руку, да 


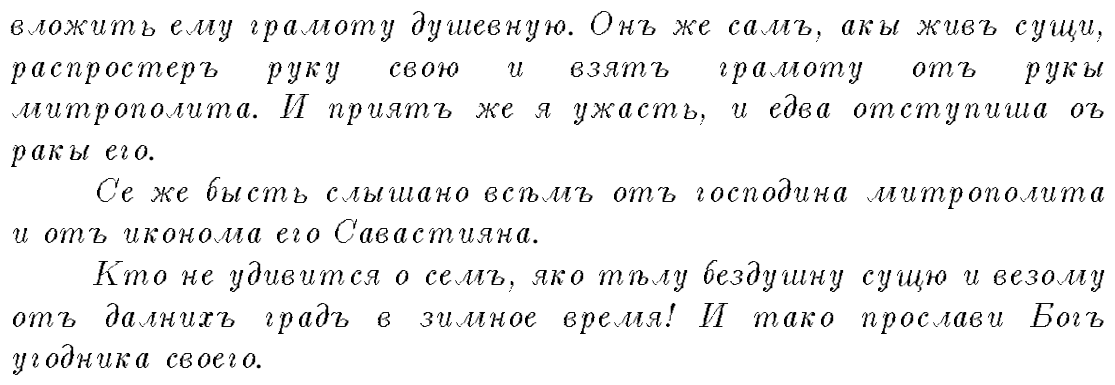

\section{Appendix B}

English Translation of Hypothetical Reconstruction of the Military Tale about Alexander Nevskii

That same year [6771] Grand Prince Alexander, son of Iaroslav, passed away. Let us speak [about] his courage and life as I have heard it from my fathers, as well as that which I was an eyewitness to while growing up.

Prince Alexander was born from a father Grand Prince Iaroslav, and from a mother Theodosia. He was taller than other men, and his voice as a trumpet reached the people. His bravery was like that of the Roman emperor Vespasian, who conquered the entire Judean land. Once, during the siege of the city of Jotapata, the burghers of the city sallied forth and defeated his regiment, and he remained alone. But he still chased their force to the city gates and thereafter he jeered at his own retinue and reproached them, saying: "You left me alone."

So also was the Prince Alexander: he used to defeat [others] but was never defeated. Once, because of this, a certain powerful man, whose name was Andreas, of those who call themselves "the servants of God," came from the Western Country for he wanted to see the marvel in the fullness of his life. He saw Prince Alexander, returned to his people, and told them: "I traveled through many countries and saw many people, but I have never met such a king among kings, nor such a prince among princes."

Hearing about the courage of Prince Alexander, the king of the Roman part of the Northern Country, thought to himself, "I will go and conquer Alexander's land." And he gathered a great force and filled numerous ships with his regiments and he moved forth with great strength being inspired by a martial spirit. He came to the river Neva and, being carried away with madness, sent his envoys, filled with pride, to Prince Alexander in Novgorod, saying, "If you are able to resist me then [do so for] I am here already conquering your land." 
Upon hearing these words, Alexander's heart burned and he led his small retinue against them, not waiting for the large force. It is a pity to hear that his honorable father, Iaroslav the Great, did not know of such an attack on his son, dear Alexander. Alexander did not have time to send news to his father for already the enemy was approaching. Even many Novgorodians had not joined him because the prince had already set out against them. He decided to go against them in the sixth hour of the day. There was a great battle with the Romans, and he killed a numerous amount of them. On the face of this king, he left a mark with his sharp spear. Here six brave men appeared.

The first was Gabriel by name, son of Alexis. He attacked a ship and, seeing there the royal prince sword in hand, he rode onto the gangway. Everyone escaped from the king back to the ship, but thereafter they turned and threw him and his horse from the gangway into the water. He got out of the water uninjured, charged them again and fought with the general, himself, among his troop.

The second, a Novgorodian Sbyslav by name, son of Iakun, on several occasions charged their troop and fought only with a battle-ax, not having fear in his heart. And several fell from his hand. The people marveled at his power and his bravery.

The third, Iakov, a man from a Polotsk clan, was the prince's huntsman. He charged the troop with a sword, and the prince praised him.

The fourth one was a Novgorodian, Misha by name, who fought on foot in the stream against the ships. He destroyed three of the ships with his detachment.

The fifth, also from his young [men], Savva by name, entered into a large, royal golden-crowned tent and cut the tent pole. When Alexander's regiments saw the tent fall, they were joyful.

The sixth, also from his servitors, Ratmir by name fought on foot and was encircled by many. He fell from many wounds several times and subsequently died. All this I have heard from my Grand Prince lord Alexander and from others who at that time took part in that battle.

In the second year after the return of Prince Alexander with his victory, they came once more from the Western Country and built a town on Alexander's patrimony. Prince Alexander went quickly against it and razed the town to its foundations. Some of the enemy were executed and others were taken prisoner.

In the third year following Alexander's victory, when he defeated the king, in the winter, Alexander went with a great force against the German land, "Let them not boast saying, 'Part of the Slavic nation is beneath us.", They had already taken Pskov town and installed their agents. Grand prince 
Alexander Iaroslavich captured them and freed Pskov town from bondage. And he waged war against and set fire to their land. He took numerous prisoners and cut others to pieces. In the towns, they got together and said, "Let us go and subdue Alexander and take him with [our] hands."

When they approached, the guards saw them. Prince Alexander drew up his regiments and went against [their] warriors. And when they came to Lake Chud there were many soldiers on both sides. His father Iaroslav sent him help [in the form of] his younger brother Andrei along with many brave men.

Prince Alexander returned from the victory with great glory. There were a multitude of prisoners accompanying his regiment. They who called themselves knights were walking shoeless next to the horses. When the prince approached Pskov town, the entire population met him in front of the town glorifying lord Prince Alexander.

And they began to hear his name throughout all countries, up to the sea of Egypt, to Mount Ararat, and on both sides of the Varangian Sea, and to Great Rome.

At that time, the Lithuanian nation was increasing and they began to sack Alexander's territory. Going out against them, he began to defeat them. During one campaign, he defeated seven armies, killed many of their princes, and captured others. Mocking them, his servants tied them to the tails of their horses. And, they began to be aware of his name.

At that time, there was a powerful khan of the Eastern Country. That khan, hearing of the glory and courage of Alexander, sent him envoys, saying, "Alexander, do you not know that God has submitted many nations to me? You are the only one who is not willing to submit to my power. But if you want to save your land, then come soon to me and you will see the honor of my khanate."

Having given due thought, Prince Alexander went to the khan. Upon seeing him, the Khan Batu marveled and said to his dignitaries: "I was told the truth-that there is no other like this prince." Bestowing on him honor, he let him go.

The great Prince Alexander went from the foreign people to Nizhnii Novgorod and stayed there a few days in good health, but when he reached Gorodets, he became ill. Woe to you, poor man. How are you able to describe the passing of your lord? How do your eyes not fall out with tears? How does your heart not break from bitter straits? A man may leave his father, but cannot leave a good lord, and if need be, he lies with him in the grave. 